\title{
Managing the Planet: The Anthropocene, Good Stewardship, and the Empty Promise of a Solution to Ecological Crisis
}

\author{
Charles Stubblefield \\ Department of Sociology, University of Alberta, Edmonton, AB T6G 2H4, Canada; stubblef@ualberta.ca
}

Received: 30 April 2018; Accepted: 29 May 2018; Published: 5 June 2018

\begin{abstract}
The Anthropocene has emerged as the dominant conceptualization of the current geological epoch and, more significantly, of Humanity's relation to nature. By its proponents the Anthropocene is espoused as a "solution formulation", an analytical tool that clarifies Humanity's multifarious impacts on nature and nature's subsequent crises, and further as a conceptual apparatus from which to launch mitigation and adaption strategies, promising deliverance from or at least engagement with ecological crises. However, the Anthropocene is not a neutral concept, merely illuminating transition within ecological conditions and connections between human activities and nature; rather, it is a particular prism from which to understand humanity's relation to nature. And, as the Anthropocene becomes ascendant both analytically and politically, it becomes vital to question its imaginary, how it constructs nature and Humanity, how it influences and constrains responses to ecological crises, and what the long-term implications of operating within this imaginary are. I argue that the Anthropocene as a political/analytical prism rests upon flawed conceptions of nature, history, and humanity, rending it an impotent construct from which to respond to ecological crises; offering only partial and presumptive "solutions" in the form of intensified governmental regulation and the application of manifold technological "fixes" through the geoengineering of Earth's systems in an attempt to address isolated aspects of ecological destruction.
\end{abstract}

Keywords: Anthropocene; nature; capitalism; ecological crisis; geoengineering; planetary boundaries; climate change; extinction; environmental crisis

\section{Introduction}

Since its emergence within the scientific lexicon in the early part of the century [1,2], the Anthropocene's use as a geological marker of time, an analytical framing device, and as a political tool has greatly proliferated; inspiring the creation of four separate academic journals to date, drawing massive attention and a fair amount of acceptance across diverse disciplines, increasingly moving from a specialized scientific concept into the popular imagination, and being recognized and venerated by both nation states and transnational organizations seeking to respond to ecological crises. This wide reception of the Anthropocene results from its political and analytical purchase, for it does far more than merely mark a new geological unit of time. Rather, it enables one to subsume diverse and seemingly disparate activities, forces, events, and processes into a condensed and comprehensible schema wherein the Environment ${ }^{1}$ and Humanity ${ }^{2}$ have entered into a novel relationship in which the

1 A term which is itself misleading, reifying a dualistic separation between humans and nature-rendering ecosystems, of which humans are apart, into a silent background or setting upon which human action takes place [3].

2 I spell Humanity here with an uppercase $\mathrm{H}$ as writers who uncritically adopt the nomenclature of the Anthropocene do not recognize humanity as collections of heterogeneous populations who have varying ways of living within and forming their 
latter has come to overwhelm and in some ways determine the former to catastrophic effect [6]. As leading figure among Anthropocene scientists, climatologist, and chemist, Will Steffen [4] (p. 32) states, "the human enterprise has now become so powerful in terms of its impact at the global scale that it rivals some of the great forces of nature".

The Anthropocene is a compelling concept and has to some extent been beneficial, exposing the effects human activities have wrought within and upon nature-initiating the planet's sixth mass extinction event [6-8]; warming the planet and altering its climate through exorbitant emissions of "greenhouse gases" [4,9-11]; triggering the warming, expansion, and acidification of the oceans as well as the subsequent death of coral reefs and other ocean life [7] (pp. 130-149) [12]; polluting and exhausting the Earth's fresh water supply and landmass through intensive agricultural practices, mining, deforestation, and wasteful consumption; irradiating the planet through the prolific use of nuclear weapons; etcetera ${ }^{3}[1,2,8,13]$ - rightly associating the manifold ecological crises arising within the contemporary world to the interactions humans have with nature. However, what the Anthropocene elucidates with one hand it conceals with the other, pointing to the activities of humans as the source of ecological crisis while simultaneously obscuring the diversity of human relations with nature and the systems under which these relations emerge-universalizing the current dominant mode of human interaction with nature to all peoples throughout history.

Thus, the Anthropocene is far more than a mere act of nomenclature ${ }^{4}$ but is also a conceptual frame or prism from which to understand humanity's relation to nature. Furthermore, and more significantly, this prism both constrains and stimulates responses to ecological crises, legitimizing certain paths forward while delegitimizing and eclipsing others. Indeed, the Anthropocene has since its formation ${ }^{5}$ been conceived of as both an analytical and political schema or "solution formulation", as Steffen et al. [5] has referred to it, advancing certain responses to ecological crises which are grounded in the Anthropocene's worldview. And, as the discourse of the Anthropocene becomes ascendant within the academic, governmental, and popular imaginary it is vital that we ask ourselves what path this schema leads us down; is it towards a more sustainable and affirmative relation with nature or does it offer false hopes, well-intentioned but hollow solutions to ecological crises?

In response to this question, this essay seeks to survey and assess the dominant Anthropocene literature drawing out key themes, problematizing and highlighting its limitations and assessing the Anthropocene's potential to facilitate effective responses to ecological crises. It will be shown that the Anthropocene as a political/analytical prism rests upon flawed conceptions of nature, history, and humanity and that these conceptions render the Anthropocene an impotent construct from which to respond to ecological destruction-offering only partial and presumptive "solutions" in the form of intensified governmental regulation over the Humanity and nature it fabricates and the application of a myriad of high-risk, piecemeal technological "fixes" through the geoengineering of the Earth's systems. That is to say that, the imaginary of the Anthropocene is incapable of producing realistic responses to the ever-emerging ecological crises of our time, because at its core this imaginary rests upon misconception, a reduction of both nature and humanity's ${ }^{6}$ diverse modes of interacting with and creating nature. As such, nature, humanity, and history are all stripped of their complexity and interconnectedness; and technological advancement and scientific management arise as the sole

environments. Rather, they conceive of Humanity as homogenized or as an aggregate actor, increasingly impacting the world as a unified force [2,4-6].

3 This list shifts and expands with each subsequent year of research but always emphasizes the increasingly precarious position that both human and non-human nature finds itself in, due to these activities.

4 See Eileen Crist [14].

5 See Crutzen and Stoermer [1] and Crutzen [2].

6 I spell humanity here with a lowercase h to signify that the difference between Humanity as an aggregate entity or unified force and humanity, as a diverse panoply of humans existing within and interacting with nature through a myriad of cultural, economic, political, and spiritual webs of meaning. 
impetus of change. And it is this misconception which engenders the earnest but ineffectual solutions of the Anthropocene.

The Anthropocene as solution formulation, then, seeks to respond to and regulate Humanity's relation to nature; rather, than addressing the current unmanageable relation that particular humans have developed with nature through capitalism; displacing capital's ceaseless need for expansion and its degradation of the planet through economically inexpensive but destructive practices of accumulation and externalization onto Humanity as part of human ontology. Through this displacement accumulation, consumption, and waste are rendered anthropogenic, the obligatory consequence of human-nature relations [7,15] and societal "evolution"7 [15]. Furthermore, with ecological destruction being misallocated onto Humanity, its numbers, and its technology (which is understood to direct and propel Humanity), the only responses to ecological crises that can arise from the imaginary of the Anthropocene is that of intensified and scientifically informed governmental observation and regulation of the legions currently seen to be ravaging the planet, and through the scientific engineering of the planet's systems-an enfolding of nature and Humanity under the control of scientific management and technology. As such, the "good stewardship" of the planet offered up by the "Anthropocenologists" 8 [1,2,4,5,18,19] aims to set limits to Humanity through government and to orchestrate nature through technology but leaves the economic system that drives the current destructive activities that devastate nature uncontested. In leaving the root cause of ecological crisis unexamined and unchallenged, the Anthropocene is powerless to address ecological destruction and is instead left addressing the epiphenomena of capital. The solutions offered up through the Anthropocene may very well enable certain lifestyles, particularly those of the wealthy in Europe and North America, ${ }^{9}$ and even prolong capitalism's modus operandi relatively undisturbed into the future, at least for some time, but it will not reverse nor halt ecological devastation. As such, if we wish to address ecological destruction we must move beyond the faulty imaginary of the Anthropocene to a novel way of imagining our relation to nature and how best to live with the rest of nature.

To illustrate the limitations of the Anthropocene as a "solution formulation", this paper will map out the discourse of the Anthropocene demonstrating that it represents both an analytical and political schema which prescribes certain responses to ecological crisis, that rest upon reductionist conceptions of humanity, nature, and history. Following this, it will be argued that capitalism serves as the primary modality through which much of contemporary humanity interacts with the rest of nature, saturating and directing both of the intersecting social/ecological spheres. ${ }^{10}$ It will be shown that capitalism necessarily functions through destructive acts of production, consumption, and externalization, so that any adequate response to ecological crises must grapple with capital. The next section of the paper will then return to the Anthropocene's promise of solutions in the face of ecological crises, elucidating how these solutions form an inadequate, piecemeal net around humanity and nature that offers at best a largely ineffectual means of impeding ecological destruction and at worst carries the potential to exacerbate it. Finally, it will be argued that more fruitful responses to ecological destruction can only be found through radical reimaginings of humanity's relationship with each other, property, and nature.

7 This continued theme of societal evolution, however, is not limited to the Anthropocene but runs throughout Earth Systems Science literature and through much of the social sciences; drawing upon and reifying the Eurocentric and erroneous narrative of cultural progress that has haunted academic thought since the Enlightenment [16].

8 This is a term which I have borrowed from Bonneuil and Fressoz [17], denoting those who have uncritically taken up and promote the term Anthropocene as the title for our current time.

9 As Will Steffen [4] points out, climate change has been and will continue to be highly unfair, impacting less wealthy regions such as Africa and South America, which have had far less of an impact on the Earth's systems, to a much greater extent than North America and Europe which have been the epicentres of this crises' formation.

10 These spheres, while not completely determinate of one another (hence the analytical separation), should not be considered separate and distinct from one another. As Richie Nimmo [20] (p. 180) demonstrates in his excellent analysis of apiculture, the social, and by extension economic, agency of humans is "shaped by the co-presence of multiple and inter-acting, material discursive, and biosocial networks". 


\section{The Construction of Nature and Humanity through the Lens of the Anthropocene}

While the concept of the Anthropocene reflects the past and present nature, scale and magnitude of human impacts on the Earth System, its true significance lies in how it can be used to guide attitudes, choices, policies and actions that influence the future-Bai et al. [21] (p. 351)

Humanity's perceived relation to nature has undergone various transformations within scientific and popular imaginary, with humanity at times being seen as the primary determinant over the operations of nature, to being understood as operating upon a largely indifferent, unfazed, and inexhaustible planet. As Spencer Weart [22] points out, these perceptions are historically determined, emerging and transforming through shifting political/scientific discourses which serve to reify certain conceptions of $\mathrm{H} /$ humanity and nature. Recently, with the emergence of new scientific data and new fields of study, which examine how human activities influence environments, "humanity"11 as an analytical abstraction has undergone a further transformation, emerging as an aggregate entity, a gargantuan figure that, for the most part ignorantly, acts upon and in some ways determines nature [23]. ${ }^{12}$ This new imagined figure of the Anthropos is one that holds extreme power, overwhelming Earth's natural forces through its exponential growth and destructive consumption habits [6], both of which are enabled through its advent of novel technologies that have served to facilitate its expansion, consumption, and as many have argued its "progress".

This chimerical figure of the Anthropos has emerged alongside another "novel" construct within scientific discourse, the "Earth System" [24], wherein the imagined environment and its interactions expands from the immediate territory or surroundings of an individual, site, species, or nation to a comprehensive interlocking apparatus composed of all the natural systems of the planet. ${ }^{13}$ Through the imaginary of the Earth System the environment becomes conceived as the manifold intersecting interactions between various natural systems dispersed over the entirety of the planet wherein the alteration of one such system, even if done on the opposite side of the world, has the potential to alter the functioning of various other systems across the globe. Together, these two emergent conceptions, that of the Anthropos and the Earth System, have come to underpin the concept of the Anthropocene and the related and intersecting field of study, Earth System Science [24].

The Anthropocene employs both these contemporary conceptualizations of Humanity and the Earth System in its construction of human-nature relations, one which sees the increasing influence of Humanity over that of nature [24]. From the perspective of the Anthropocenologists, the Earth's systems themselves have, within the past two centuries, undergone such dramatic alterations at the hands of humans that it merits a new title within the geological timescale, one that reflects the agents that have come to shape the planet, arguing that the planet has left the relatively calm Holocene epoch which began approximately 11,700 years ago [25] (p. 1) and entered a new epoch marked by Human primacy over the Earth. As evidence to this, the Anthropocenologists point to a myriad of "anthropogenic" changes wrought by human activity. These changes are demonstrated in manifold graphs and statistics that depict the exponential growth and resource use of Humanity as well as the impact human activities have had on the planet, ranging from the rise of carbon particles in the atmosphere; to the amount of fresh water supply expended; to the increased extinction rate ${ }^{14}$;

11 Indeed, the laborious and incomplete transition from the masculine moniker of Mankind, which served to silence the role of women throughout history, to the more inclusive term Humanity is evidence of how continuing political/scientific debates both render the human population as a totality thinkable while also serving as an exclusionary practice.

12 See also, Crist [16].

13 This transition did not happen all at once but over decades. However, two large events were indispensable for the Earth System to be made thinkable: first, the International Geophysical Year of 1957, where 20,000 scientists from 67 nations worked in conjunction to study the Earth's functioning [24], and second, the emergence of the 1972 "Blue Marble" photo of Earth taken by NASA [17].

14 Estimated to be between 100-1000 times the "background rate" of extinctions that would occur naturally [25]-that is without the prodigious impact of the Anthropos or, rather, unsustainable human-nature relations (see below). 
to the percent of landmass used for agriculture, business, and housing; to the number of McDonald's restaurants existent within the world ([5,6] (pp. 617-620) [13,19] (pp. 851-852) [26,27] (pp. 15-17) [28]). Furthermore, these effects, as has been elucidated by the Anthropocenologists, have been etched into the Earth's atmosphere, biosphere, and topography with dramatic increases in the amounts of carbon present in the atmosphere, massive extinctions both ongoing and looming [7], and the Earth's surface itself being irradiated with Caesium 137_the bioproduct of above-ground and near-surface nuclear explosions [29] (pp. 81-89).

It is with this evidence that the Anthropocenologists make their compelling case to rename the epoch, correctly calling attention to the roles human actions play in disrupting ecological functions and instigating extinction. However, as Bonneuil and Fressoz [17] (pp. 53-56) point out, these graphs and statistics present a history of curves and stages wherein changes within human sociality and human-nature relations are taken to be the result of technological advancement and the succeeding stages of human progress. History is expunged of its contention, variability, and conflict through the Anthropocene's facile macro view of the past, which focuses upon the developments that were, often with an emphasis on Europe and North America, rather than the potentialities that existed and continue to exist. ${ }^{15}$ As such, the Anthropocenologists seek a discernible rise in "anthropogenic" effects on nature and look backward toward the technology that is assumed to have incited the augmentation of human-nature relations. One can see this propensity in the proposed dates for the dawn of the Anthropocene that wholly center on technological advancement-with the invention of fire and the subsequent rise of $\mathrm{Co} 2$ [30], the rise of agriculture during the mid-Holocene and its subsequent increase in $\mathrm{Co} 2$ [6], the more popular date of 1800 marked by the James Watt's 1784 invention of the rotary steam engine and again the ensuing rise in $\mathrm{Co} 2[2,31]$, and finally the so-called "Great Acceleration" of the post-World War II period where there was a massive spike in new technologies, such as the atomic bomb, as well as a myriad of "anthropogenic" impacts on the environment [28]. This history of innovation and natural effect does not question how things came to be but takes the quantifiable rise or decline of transformations within the Earth's systems as evidence for both the existence of the Anthropocene and qualitative changes within human-nature relations.

This slightly troubling and reductionist understanding of history, which will be returned to in more detail below, does not in itself warrant an overly severe critique. However, as Jason Moore [32] points out, the Anthropocene does far more than label an epoch within an isolated field of study but promulgates modes of thought, engendering ways of seeing and engaging the world. And, even more disconcerting, the Anthropocene makes the Humanity and nature it imagines both knowable and thus governable in new ways. ${ }^{16}$ As the Anthropocene discourse has become increasingly dominant across fields of study and as governmental organizations such as the United States and United Nations have begun to mirror scientific and environmental discourses such as the Anthropocene [35-37] developing a lingua franca that runs across these diverse spheres of power, it is vital that we examine the way that this discourse imagines responses to ecological crises and that we address this imaginary's shortcomings.

Indeed, from its very inception, the Anthropocene has offered both name and response to ecological crises [1,2]. As a name, the Anthropocene has to some extent been fruitful in serving as an intelligible conception that has facilitated discussion across divergent fields of knowledge and

15 Indeed, even when, in passing, the Anthropocenologists acknowledge that some nations and peoples have historically contributed little to the ecological changes marked by the Anthropocene, the title is vehemently defended by noting the current rise in "anthropogenic effects" emanating from the Global South and other regions, thus maintaining that our human-nature relations are determined by technological development and progress-again ignoring the social, political, and economic drivers for such a change and universalizing the current dominant mode of interacting with nature to all peoples both past and present.

16 Promoting some to draw on Foucauldian lines of thought to understand and critique the emergent governmentalities arising from the novel environmental and Anthropocene knowledges. For excellent examples see-Lövbrand, Stripple, and Wiman [24]; Luke [3]; Luke [33]; and Parenti [34]. 
enabled thought to move beyond oversimplified and partial conceptualizations of climate change, localized views of pollution, isolated understandings of extinction, etcetera towards a more holistic understanding of diverse ecological crises as bound together through their relations to human activities ${ }^{17}$. However, both the term Anthropocene and the discourse that commonly surrounds it are, as has been widely noted, highly problematic $[8,14,16,17,32,38-49]$ obscuring as much as it reveals, reifying the same Cartesian dualism separating humanity from nature that it professes to transcend, misinterpreting and misrepresenting historical change, variability, and conflict, and agglomerating and homogenizing humanity as uniformly and innately at odds with and destructive toward its natural surroundings and the other beings that reside within them.

These views imbued within the Anthropocene concept are tied to its employment as a political device for the Anthropocene literature advances more than a value-free name, if there can be such a thing, for the epoch; but, rather, the Anthropocene simultaneously advances certain responses to ecological crises. Being touted as a "solution formulation" [5] (p. 741) by its main proponents and referenced as the rationale for "good stewardship" of the planet $[4-6,18,19,25,26,50,51]$, as well as similar calls for humanity to enter into a contemporary "noosphere"18 [2,52], in which the planet is enveloped under the supervision of expert knowledge and technological administration. As Paul Crutzen, the Nobel Prize winning atmospheric chemist, seen by many as the founding figure of the Anthropocene concept, states in his oft-cited "Geology of Mankind"19 [sic]:

A daunting task lies ahead for scientists and engineers to guide society towards environmentally sustainable management during the era of the Anthropocene. This will require appropriate human behaviour at all scales, and may well involve internationally accepted, large-scale geo-engineering projects, for instance to 'optimize' climate. [2] (p. 23)

This use of the Anthropocene as a political device while a reoccurring theme throughout Anthropocene literature has intensified with each subsequent year of publications. Where once this body of literature primarily sought to vindicate the new designation for the epoch and secondarily proposed potential responses, there has now been an evident shift in its emphasis, with authors gradually transitioning their primary focus to the management of ecological crisis. Manifold articles have now emerged that employ the Anthropocene concept as a means to address emergent environmental issues. These articles while not totally unified in content, largely yield two general responses to ecological degradation. The primary and by far most favored response is to enhance existing as well as to construct novel forms of governance that will serve to supervise, regulate, and manage Humanity and nature. This response proposes to place quantifiable scientific data in the form of nine planetary boundaries—climate change, biosphere integrity, land-system change, freshwater use, biochemical flows, ocean acidification, atmospheric aerosol loading, stratospheric ozone depletion, and novel entities $[25]^{20}$ - that humanity cannot cross without causing undue risk to the Earth System as well as ourselves, at the heart of governmental programs. It is important to note that this proposal for governmental regulation of the Earth's systems are not merely an ambiguous call for conservation or regulation but for increasingly fine-tuned programs with meticulous quantifiable measures of human-nature relations both globally and regionally [25] that could, hypothetically, be applied at any time.

17 This value of the Anthropocene concept has similarly been noted by Jason Moore [32,38,39].

18 This is a term which Paul Crutzen borrows from the earlier twentieth century French Jesuit priest P. Teilhard de Chardin and E. Le Roy (see Crutzen [2,52] and Steffen, Crutzen, McNeil [6]) which denoted the increasing supremacy of human thought over the functionings of nature.

19 This title itself reveals the paradoxical quality of the Anthropocene, claiming that Humanity as an aggerate entity represents a new geological force while at the same time excluding women through its use of the title of "Mankind"; assigning great power to men, who have the capacity to shape the world, while still rendering women invisible.

20 While Rockstörm et al. [18] is the most widely cited article on the nine planetary Boundaries, having been presented before the UN, I have chosen to use Steffen et al. [25] for this essay as it is the most up to date version of the planetary boundaries model, having made a number of amendments to the previous work. 
The second and related response commonly offered up through Anthropocene literature is that of geoengineering the Earth's systems, with authors proposing massive projects that would serve to manipulate the Earth's systems through the strategic deployment of technologies. These projects range in their methods and desired outcomes but can be broken into two primary groups: (1) technologies that sequester carbon dioxide from the atmosphere for storage and/or further use as an energy source and (2) techniques that modify the radiation balance on the Earth's surface by altering the incoming solar radiation that is absorbed by the planet [4] (p. 29). ${ }^{21}$ Of these geoengineering techniques, by far the most commonly proposed option is the seeding of the atmosphere with sulphur aerosols that would serve to reflect incoming light back into space, thus reducing the temperature of the planet and addressing, at least in part the ecological crises that results from global warming [2,4] (p. 28) [6] (pp. 619-620) [9,10,54]. However, while these proposed responses emerging from the Anthropocene promise salvation in the face of ecological devastation, they will fail as they are built upon a faulty understanding of human-nature relations. As such, they address the wrong issue and do little more than enable the current destructive relations that exist.

For, at the heart of the Anthropocene's distinctive world view is a peculiar dualism that reifies a problematic separation of Humanity from nature. As Dipesh Chakrabarty [55] and Nancy Tuana [56] point out, the Anthropocene holds out the potential to transcend the silently assumed dualism that haunts much of environmental thought, clearly demonstrating that Humanity is imbedded within, entwined with, and vulnerable to nature. This view is common throughout the Anthropocene literature, arguing that as Humanity is undoubtedly contained within and impacting nature through its activities and as nature can be seen to be responding reciprocally to those human activities, that both Humanity and nature must be understood as existing as a singular interconnected system [19,27,52]. However, while the Anthropocene may appear to escape dualism by placing humanity back into nature and underscoring reciprocal relations between Humanity and nature, it never fully escapes dualistic modes of thought, quickly retreating back into dualistic models of human-nature relations within an altered "unity" made up of divided systems.

As Jason Moore [39,47] points out, the Anthropocene concept is plagued by what he refers to as "one system, two systems" contradiction, which is pervasive throughout environmentally oriented scholarship. On one hand, the Anthropocene recognizes that humans are a part of nature both acting upon and subject to the "great forces of nature". Thus, humans are recognized as internal to the operations of natural systems (one system). On the other hand, Humanity is rendered as separate and distinct from nature, as Society ${ }^{22}$ and social organization are abstracted from the operations of nature (two systems). Biology and geology (physical forces) are maintained as altogether separate from social systems (mental forces). As Zalasiewicz et al. [57] argues there are "human constructions" and "Natural constructions", with feedbacks running between the two systems where one system may alter and impact the other, but with the two systems being understood as in essence distinct from each other. The dualistic Cartesian separation of mind and body is refracted and warped to some extent, but is fundamentally maintained within the Anthropocene imaginary, in what Moore refers to as "green arithmetic" — wherein "Nature plus Society equals the Whole" [47] (p. 4).

This view is problematic for a number of reasons. First, and most blatantly it is incorrect, natural systems and human sociality are not so easily kept separate but are continuously interconnected; human activity may very well, and always does, modify nature, but only does so in so far as it is embedded within, reliant on, and a part of nature. For, as posthumanists so poignantly remind us, human "agency is shaped by the co-presence of multiple intra-acting material and discursive and biosocial networks, such that human intentions are merely one element in an open-ended and dynamic

21 For a thorough examination of the various proposed geoengineering techniques and their limitations, see The Royal Society [53].

22 Society is spelled here with an uppercase $S$ as it operates as a unified actor within much of the Anthropocene literature. 
ensemble of more-than-social relations" [20] (p. 180 ${ }^{23}$. In fact, society, human agency, and human activity cannot be conceptualized sensibly outside of the co-presence of other species and the flows of nature; we are constantly in relation to the rest of nature: as we dig in the ground to access the energy of long dead organisms, rely on insects for our agriculture [20], plants for our sustenance and to absorb the carbon emitted into the atmosphere, we find ourselves at every turn reliant on and bound to nature and the sun that provides the Earth its energy and that drives its flows-what society or human can be imagined to operate independently of nature? Thus, the feedback system between Society and the environment constructed within the discourse of the Anthropocene wherein human activity is still seen as functionally, though not straightforwardly, distinct from the co-presence of nature is innately flawed, reifying the Cartesian dualism between nature and Society it promises to transcend.

The second and more worrisome issue is that this bifurcation between Society and nature upon which the Anthropocene concept operates has been instrumental to the rise of climate change and ecological destruction. As Hasana Sharp [49] (p. 276) points out,

The near limitless exploitation and instrumentalization of nonhuman nature is supported by the metaphysical portrait of ourselves as uniquely minded, distinctively sensitive, and fundamentally different in kind from all other beings in nature.

For it is this perceived exceptionalism which has enabled humans, particularly those who have traditionally held lopsided power within society $[38,47,49]$, to denigrate and treat nature, other species, and "lesser" humans [38,47] as a resource to be used for gain. As nature is estranged from Humanity and rendered into the background of the "environment" and as Humanity is elevated above that of nature, nature is devalued and made consumable; one need only look at our current ruinous relation to cattle that we have rendered into "livestock" and that we now factory farm [59] to see how our use of nature for gain is bound up with a perception of human superiority over that of nature and other species. The Anthropocene retains this form of exceptionalism and expands upon it, even intensifying it. For, as has already been suggested, the Anthropocene demands not that humans reduce their influence over the rest of nature nor does it demand fundamentally new relations between humans and nature but, rather, demands that humans take a firmer grasp upon nature, to supervise it, and regulate it like the factory manager of Taylorism, ensuring that it functions at optimal capacity for the benefit of humans [2] (p. 23) with little to no regard for other species involved.

This brings us to the third and most pressing issue with the dualism that undergirds the Anthropocene: the bifurcation of Humanity and nature itself frames what should be examined and how best to address ecological crises $[38,39,47]$. On one hand, this dualism makes invisible the bundle of extra-human relations in which humanity is immersed, and on the other, it presents a view of Humanity as innately overwhelming the Earth System and thus guides responses to ecological crises away from addressing those relations and toward the management of the Earth's systems and Humanity. This is why we see a rise in neo-Malthusian concepts of over population and the treating of the population itself as determinate of human-nature relations within the Anthropocene literature - as it is understood to be the quantity rather than the relations of and between humans and nature that are a primary driver of ecological crises. And, as our current relations become naturalized through the dualism of the Anthropocene, Humanity's numbers emerge as the issue which must be compensated for if we are to maintain a stable Earth System. Furthermore, nature too must be remade and enhanced, "optimized" 24 so as to provide for Humanity and to absorb its prodigious excesses. Thus, while the Anthropocene concept holds out the promise of transcending the Cartesian dualism implicated in our destructive past with nature, it serves to reify and intensify it to new levels as the entire planet must be subjugated in service of Humanity, and Humanity itself comes to require

23 See also Haraway [42,43], Sharp [49], and Van Dooren [58].

24 See Crutzen [10] (p. 23). 
expert supervision and guidance in order to maintain a habitable balance between the two distinct systems. And finally, through this maintained dualism of the Anthropocene, responses to ecological crisis are reduced to those that can manage Humanity and nature, as social relations, systems or power, and human-nature relations, etcetera are all rendered invisible.

There are those who, while seeing the limitations engrained within the Anthropocene concept, will still argue that its dualism is a necessary depiction of human-nature relations [60-62], claiming that it would be foolish if not a dangerous form of escapism to rescind our exceptionalism at the height of our impact upon nature. However, this acceptance of the title Anthropocene appears dangerous for two reasons: first, the Anthropocene still miscomprehends and misallocates responsibility for ecological crises onto an undifferentiated Humanity, when it has only been some humans at particular times and within particular relations that have driven ecological crises; and second, as has already been mentioned, the Anthropocene, based on its views of Humanity and nature, produces only certain limited and problematic responses to ecological crises. ${ }^{25}$ Furthermore, there are also those who recognize the Anthropocene's dualism as problematic but argue that we should not abandon the concept, but rather that those in the Humanities should work to shift its meaning away from its reductionist tendencies $[45,63]$. These arguments while conceivable ignore the power dynamics present between the "hard science" creators of the Anthropocene concept and those within the Humanities who may wish to shift its meaning. The Anthropocene concept has already been roundly criticized to no avail, and the Anthropocenologists, while regularly inviting those within the Humanities to take part in research, have clearly assigned the Humanities the role of measuring and regulating the human phenomenon and have not afforded an equal position to those outside the biophysical sciences as co-authors of the Anthropocene. As such, it seems highly unlikely that the Humanities will be able to dramatically alter the concept constructed and maintained by those resistant to such change. ${ }^{26}$ However, while this dualism is highly problematic, it is not the only limitation of the Anthropocene imaginary, as it also strips history of its complexity and privileges technology as the driver of historical change and ecological crisis.

\section{Technology, Humanity, and the Anthropocene's Conception of History}

We have mistaken who "we" are (as some kind of undifferentiated human mass) from what "we" perform through capital. We have mistaken a historical condition of our economic organization for an innate aspect of the human being-McBrein [8] (p. 85 [emphasis in original])

As has already been pointed out, the Anthropocene amalgamates Humanity into a singular actor or rather, a legion of actors generally interacting with nature in the same manner, with this massified abstraction of Humanity serving to legitimizing the Anthropocene's response to ecological crises. However, this subsuming of humanity-a diverse species spread throughout the globe and history, and operating according to and through interconnected webs of cultural, discursive, and extra-human relations - under Humanity, obscures both the current diversity within human societies as well as the historical variability within history. Indeed, the Anthropocene renders history as unified, linear, and progressive-Humanity advances, grows in population, and influence over nature with the production of novel technologies. Why and how these technologies came to arise in a given time and place is unimportant, as it is the technologies and not social relations that are deemed to be the determining factor for change and "progress". However, as a contemporary look at the world would demonstrate $[66,67]$ and as an examination of history would show [68-71], humanity has

25 For a more thorough examination and critique of Colebrook's defence of dualism in the Anthropocene, see Sharp [49].

26 There is also the issue of intellectual status, with the "hard sciences" being revered more in the popular imagination and by governmental organizations, prompting some, such as Anna Tsing [64] and Ashely Dawson [65], to promote the construction of new radically democratic alliances and blendings of the natural sciences, Humanities, and public spheres so as to avoid such constraining elitisms and one-dimensional views (see below). 
never been unified in its existence and relation to nature, always existing in manifold ways through webs of meaning that are bound to a myriad of social, discursive, technological, and extra-social relations. Technology may and does facilitate the expansion, influence, and means of cultures, but it is not determinate of them [72], always emerging from within and bound to specific historical and cultural systems [68,69]. To take the most pertinent example from history, we can see that the rise of steam power and the consumption of coal was not the impetus for social change and industrialization, as the Anthropocenologists suggest, but was itself the result of pre-existing social, political, and cultural realties.

Within the Anthropocene literature, the emergence and progression of steam power is commonly recognized as an-if not the-primary driver for Humanity's transition into the new epoch. Within this frame, steam and coal are not only understood as the means by which carbon is released and ecological destruction results, but, rather, they are understood to be determinate of Humanity's mode of interacting with nature. That is, fossil fuel use is envisaged as establishing the current pattern of human interaction with nature, one that did not necessarily revolutionize Humanity's innately destructive relation to nature but rather revolutionized Humanity—causing an explosion in population, the growth and spread of industrialization, and setting the modus operandi for Human accumulation of nature and thus Humanity's interaction with nature. As Steffen et al. [19] (p. 848) states:

One feature stood out in the world that humanity left as it entered the Industrial Revolution; it was a world dominated by a growing energy bottleneck. The primary energy sources were tightly constrained in magnitude and location. They consisted of wind and water moving across the Earth's surface, and on the biosphere, plants and animals... The discovery and exploitation of fossil fuels shattered that bottleneck... Exploiting fossil fuels allowed humanity to undertake new activities and vastly expand and accelerate the existing activities... The result of these and other energy-dependent processes and activities was a significant increase in the human enterprise and its imprint on the environment. Between 1800 and 2000, the human population grew from about one billion to six billion, while energy use grew by about 40 -fold and economic production by 50 -fold.

From the perspective of the Anthropocene, technology becomes the catalyst and basis for human-nature relations, determining Humanity and subsequently nature. Even when acknowledging that economic growth is tied to ecological destruction, the significance is still placed upon the technology and energy advancement and not upon the mode of production, which is seen as a consequence of technology. This is why we see the Anthropocene being dated around technological change with the emergence of fire, agriculture, and the steam engine and not the arguably more ecologically and geologically impactful Columbian exchange. ${ }^{27}$ Through the lens of the Anthropocene James Watt's steam engine emerges as the catalyst for Humanity's current mode of interaction with nature and the crises of our time, being accorded as the labor pains if not the birth of the new geological age of "Mankind" [sic] [2,52]. However, this view in its preference to valorize technology as the basis for historical change excludes the rationales and motives for the adoption of fossil fuels and production processes and as such forfeits its capacity to grasp our current ecological predicament.

Counter to the 1784-1800 date commonly given within Anthropocene literature as the starting point of Humanity's dominance over nature through the adoption of fossil fuels, the advent of steam power and a novel increase in large-scale production and consumption, the current organization of destructive relations between some humans and nature had already begun in the mid to late 15 th century with the rise of novel social relations, primitive accumulation,

27 To my knowledge, no formal proposal has been submitted to date the Anthropocene's beginning in the 15th or 16th century. This is surprising given the massive biological and ecological changes that occurred as a result of the meeting of the "old" and "new" worlds with a range of species and diseases crossing the ocean, the death of up to $90 \%$ of the indigenous population [47] (p. 26), and the regrowth of the American forests and the subsequent decrease in Co2 [8]. 
and proletarianization ${ }^{28}[8,38,39,47,68,70,71]$. Large-scale factories mass producing consumer goods had emerged well before the adoption of steam power, with factories predominantly utilizing water wheels and the power provided through natural streams and rivers [68,69]. Fossil fuels, such as coal, were also already a major commodity in Europe ${ }^{29}$ by the 1530 s and its use had exploded by 1630, with 1.5 million tonnes of coal being produced in England that year alone [47] (p. 16). While colonialism ${ }^{30}$ and large-scale deforestation for lumber and the imposed production of mono-crops [73] (pp. 197-219) were already reshaping the biology, geology, and geography of the world as early as the end of the 15th century, with major increases in their impact by the 17th century. Indeed, as Jason Moore points out [47], mass deforestation for the industrial production of potash, used for the bleaching of cloth, had already led to the clearing of approximately a million hectares, and possibly far more than that, of forest from the Vistula Basin alone between 1500 and 1650 - not to mention other numerous waves of deforestation and ecological destruction instigated in the pursuit of commercial agriculture and mining, which all predate the $1784-1800$ date given by the Anthropocenologists. ${ }^{31}$

Furthermore, as Andreas Malm illustrates in his excellent essay, "The Origins of Fossil Capital" [69 $]^{32}$, steam power did not gain immediate acceptance following Watt's invention; rather, it took decades for coal-fuelled steam power to be common within factories, only being widely utilized in the mid to late 1820s. As Malm points out, the use of coal for commercial production was first largely deployed within the English cotton industry as a source of energy for steam power. However, this change to accept coal-fired steam power within factories was not the result of steam's perceived superiority over water power but, rather, the result of a number of social, political, and economic changes in England. In fact, industry, for the most part, was initially opposed to the use of steam power as coal was seen as an unnecessary and persistent cost, needing to constantly feed purchased coal into expensive machines prone to malfunctioning when compared to free-flowing power of water that drove machines that could function for more than a century with minimal maintenance $[68,69]$. As Malm elucidates, it was only after the massive explosion of the urban population following the proletarianization of much of the English peasant class, juridical changes mandating a 10-hour working day that served to disrupt the variable work schedules of companies using water wheels (which had fluctuating schedules dependent upon the natural flows of water), and the decrease of coal's cost with its increased production that coal became widely used as a source of energy. It is these changes, and not the mere invention of the rotary steam engine which drove the early capitalists to move their factories from the streams of the countryside to the cities, where labor power was cheap and easily replaceable and work could function regardless of legal and natural limitations. Coal did add new efficiencies, enabling energy to be consumed on demand regardless of the time, location, and season. But this was not at the heart of why coal was accepted; rather, as Malm illustrates, it was the possibility of reducing the costs of human labor power through the increased competition present within cities and the ability to increase the output of items to be sold for consumption that formed the heart of fossil fuel's acceptance.

Thus, it was the social relations of capitalism that formed the basis of the industrialization that the Anthropocenologists point to as the origin of the Anthropocene. Furthermore, as Malm [69] (p. 17) so potently points out, "fossil fuels should, by their very definition, be understood as a social relation:

28 This is not to argue that prior to this time humanity "lived in peace with nature". It is clear that human-nature relations have been diverse throughout history, with some being more destructive than others. Rather, this is to argue that capitalism represents a qualitative shift in both human-social/human-nature relations to a new and highly destructive apparatus.

29 Furthermore, China had been using coal for centuries without causing a new geological epoch, suggesting that it is more than fossil fuel use at the heart of our new relation with nature.

30 As Moore [38] points out, colonialism and capitalism should not be considered a singular phenomenon. However, the two do overlap in such a way that they cannot be separated, nor can one be understood without the other.

31 For a more thorough examination of ecological destruction instigated under capitalism prior to 1784, see Moore [47].

32 See also Malm [68]. 
no piece of coal or drop of oil has yet turned itself into fuel. No humans have yet engaged in systematic large-scale extraction of either to satisfy subsistence needs". Commodity production and capitalist labor relations predate and incited the rise of industrialization. However, this crucial sequence of events has eluded the Anthropocenologists, causing them to place historical impetus on technology and energy over that of social relations and the mode of production.

As Daniel Hartley [41] (p. 156) points out, the Anthropocenologists have developed a "one-on-one billiard ball model of technological invention and historical effect". ${ }^{33}$ This model is devoid of historical processes, conflict, and motivation merely taking quantifiable increases in "human" impact in the form of carbon present in ice cores, the amount of radiation infused in the soil, or some other tangible marker of ecological distress ${ }^{34}$ and seeking the correlative technological development as a means to understand historical change. One glaring example of this mechanical view of history imbued within the Anthropocene can be found in Steffen et al.'s [5] (pp. 743-744) I = PAT equation. This equation argues that the overall human impact on nature (I) is equal to the population (P) times Affluence (A) "an indicator for consumption" [5] (p. 743) times technology (T). All three measures are considered to be innately tied to adverse effects on nature, with no assessment of history, culture, extra-social relations, or the mode of production being necessary to understand how, why, and to what extent humans impact nature. And here again, even when we see some small charge brought against exorbitant consumption, in the form of affluence, this same paper reaffirms economic growth through "greener consumption" and technological fixes that would serve to reduce necessary throughput while maintaining current lifestyles. Thus, technology emerges as both the driver and solution for environmental crises, while social relations, human-nature relations, and the mode of production are rendered mute through the Anthropocenologists misconceived and reductionist conceptualization of history, humanity, and nature.

As technology is seen to be deterministic of Humanity and Humanity's interactions with nature, technology becomes the key to solving Humanity's predicament. Furthermore, the mode of production and the relations of power which keep that mode of production operating ${ }^{35}$ are invisibilizied, omitted from critical reflection, and are thus not seen as a space for intervention. Thus, this misconceived and misconstrued history leads the Anthropocenologists to reify a world in which expert knowledges, management, and technological intervention are the only means by which the ecological crises of the Anthropocene can be dealt with. Furthermore, as Humanity is conceived of as innately at odds with nature, this management does not, in general, seek the reconciliation of the two systems into a peaceable relation where Humanity's impact is removed from nature through technology, nor do many of the authors seek to simply return to the Holocene epoch; rather, one can see alarming imaginings within prominent Anthropocene literature of a new tamed nature, one in which nature is brought even further under the influence of Humanity's conscious management, optimized and reconstructed for human needs $[1,2,5,21,52]$.

The Anthropocene discourse subsumes humanity under Humanity, stripping it of its diversity and variability and does so within an erroneous dualistic separation that ruptures human social relations from nature. Further, it reduces historical change to a linear series of technological advancements and historical effects, stripping history of its contentions, impetuses, and diversity. The result is a facile and unambiguously flawed view of nature, humanity, and history that serves to direct thought and action in response to ecological crises. Through this lens, human-social/nature relations are rendered invisible, and technology and expert management arise as the only means by which one can address

33 See also Crist [14].

34 See Steffen et al. [5] for a through list of such measures and proofs for the Anthropocene.

35 While I am conducting a largely Marxian analysis of the Anthropocene literature/imaginary, the Foucauldian lens has much to offer here and could provide a valuable complement to Marxian works. For, as Foucault [74,75] elucidates, there are power relations which both operate outside of and enable the current political and economic modus operandi. Concepts such as governmentality and political rationality could add a great deal of insight to future research. 
ecological crises. In ignoring these relations, the Anthropocenologists neglect the heart of the issue and as such debilitate any real possibility of developing an effective response to ecological crises, as any real response would require a qualitative transformation of the power structures and relations which maintain unsustainable human-nature relations.

\section{Capitalism as World Ecology}

The need for a constantly expanding market for its products chases the bourgeoisie over the whole surface of the globe. It must nestle everywhere, settle everywhere, establish connections everywhere-Marx and Engels [76] (p. 248)

As Karl Marx [71] (pp. 23, 29) pointed out a century and a half ago, capital, like all modes of production, is fundamentally a relation with nature, structuring the modes by which humanity interacts with and understands the rest of nature [41]. Capitalism, then, both structures human social relations, which are never fully isolated from relations to nature, as well as human-nature relations, as nature is organized, valued, appropriated, and exploited through the process of capital production. Furthermore, nature is not simply appropriated by capital but is actively produced through it, with capitalism both operating within nature and nature operating and being produced though capitalist modes of production in what Jason Moore refers to as a double internality [38,39,47]. Capital thus serves as a nexus through which humanity relates to and produces nature, one that has become increasingly ubiquitous within the world through processes of primitive accumulation, colonial appropriation, proletarianization, and through various rearticulations of capitalist power systems. This is, however, not to argue that capital determines all relations between humans nor between humans and nature, as many forms of power operate beyond the strictly economic and material, ${ }^{36}$ but that capital forms the primary nexus through which much of humanity has come to interact with, understand, and construct nature.

As Marx [70] elucidates, capital produces material under certain "logical" regularities of operation. These regularities push capitalists to seek the accumulation of capital through production processes that incur the least possible costs while at the same time accruing the highest possible surplus-value. Furthermore, this process of accumulation constantly reiterates itself with ever-expanding quantities of material being utilized in the production of further products for future sale. This process is summarized in Marx's now familiar equations $M-C-M^{\prime}$ and its expanded representation of $\mathrm{M}-\mathrm{C}(\mathrm{L}+\mathrm{MP}) \ldots \mathrm{P} \ldots \mathrm{C}^{\prime}-\mathrm{M}^{\prime 37}$, where an original sum of money is invested in the production of commodities for future sale with surplus-value arising from the exploitation of labor that is aided through technological innovations and the appropriation of free or cheap nature ${ }^{38}[38,39,47,77]$. This process repeats itself ad infinitum with ever increasing quantities of nature entering into this system and with ever increasing externalities being unleashed upon nature. Furthermore, as both Marx [70] and Max Weber [78] make clear, capitalist society compels those within it to reproduce its relations of production and consumption or face extinction; forcing down those who refuse to subjugate the proletariat and to appropriate nature, and quite literally threating the life of the proletariat who refuses to sell her/his labor and does not take part in consumption, be it through force or exclusion.

Similarly, as Elmar Altvater [72] points out, capital has a double character to it with two overlapping spheres of operation. The first sphere of capitalism is its value dimension consisting of

36 Indeed, social phenomena such as ecological crises, racism, sexism, ethnocentrism, etc., while all intersecting with the production of capital are not wholly determined by its relations. As such, future study should examine various social and extra-social relations which contribute to ecological crises.

$37 \mathrm{M}$ (money) - C (commodities: L + MP [labour power + means of production])... P (process of production)... C' (increased or new commodities infused with surplus-value)- $\mathrm{M}^{\prime}$ (increased money/capital). For a more thorough analysis of capital production processes, see Marx [70].

38 As Marx [77] (pp. 440-445) notes, nature on its own does not create surplus-value, as it must enter into value relations through social systems and through processes of labour. 
the monetary value of GDP/GNP, world trade, foreign direct investment, financial flows, etcetera. This sphere operates within the financialized logic described above and attributes value to nature as both resource and "sink", or dumping ground, for capital's unvalued excesses. The second sphere of capital is its material and energy flows of production and consumption, transportation and distribution, and waste management; this sphere directly shapes nature molding it through actions such as organization, appropriation, the release of new elements, etcetera. Under capitalism, as decisions are made the primary concern is placed upon the economic sphere that of value and prices, profit margins and monetary return on investment, for to do otherwise is to doom oneself in competition. Thus, the former sphere of economic rationality and profit-maximization is determinant of the material flows of the latter. This, as Altvater points out, has dramatic effects upon nature, both rendering nature indiscriminately subject to capital and its ceaseless expansion and creating a contradiction in which short-term economic goals are placed above the long-term sustainability of nature. Furthermore, the continuous growth of capitalist markets constantly intensifies this contradiction; with the total size of capitalist markets, measured in GDP, increasing at an average rate of $2.2 \%$ per year, the overall size of capitalism and its markets doubles every 30 years [29] (p. 85), requiring larger quantities of nature to pass through production, larger quantities to be consumed, and with larger quantities of waste being unleashed upon nature.

It is this process of exponentially expanding capital production, and not humanity, that is innately at odds with nature: commodifying it, appropriating it, eliminating that which obstructs accumulation, and using it as a receptacle for its unvalued excesses. For as Moore [38,39,47] illustrates, capital production necessarily generates ecological crises as it must both constantly acquire new and higher volumes of cheap nature and must dispose of the undesirable excesses of commodity production through the most inexpensive means possible. The former necessity to acquire cheap if not free nature is driven by the increasing competition amongst industry and the tendency for the rate of profit to fall-a general process in which the amount of value contained within each article produced within commodity production is reduced, as corporations attempt to out compete one another by lowering commodity prices through various activities such as the deployment of novel technologies, which serve to increase production output and lower commodity prices but that also subsequently require ever increasing throughput of raw materials or life [70]. The latter need to externalize the excesses of production has always and continues to be an immanent part of capitalism, as corporations and nations are compelled to displace the costs of growth upon nature that has until recently appeared, at least to many, ${ }^{39}$ as a passive receptacle for waste [8,22]. And, as McBrien [8] and Sarah Surak [79] remind us, capitalist growth requires externalization, ${ }^{40}$ as production that internalizes its own costs is both infeasible-how could the 90 corporations that have produced 63\% of greenhouse gas emissions [80] be able to internalize the costs of their production or be held accountable for their actions when they took place prior to the knowledge of their effects? - and by and large undesirable, for producers who need to outcompete their competitors, their consumers who routinely move toward lower costs, and nations whose legitimacy and strength is maintained by the growth of their GDP/GNP [81].

The result of these features is an apparatus which constantly monetizes, orders, and produces nature through the appropriation of its resources, the subjugation of its life, both human and extra-human, for commodity production [20,59], and the utilization of it as the depository for productions unwanted excesses and as capitalist markets continue to inflate in size these issues only exacerbate. Through its processes, capitalism unceasingly reforms nature constructing new ecologies wherever its presence is felt and necessarily tending towards crises, both economic and

39 As the Anthropocenologists point out, there have been individuals for at least the past two centuries who have noted the increasing impacts that "humans" have had on nature. For a more comprehensive review of this history, see Weart [22].

40 This is not to suggest that every commercial enterprise must always externalize its costs, as companies can market their "green" production, but rather that capitalist economies as a whole are imbued with this prerequisite to reduce costs as much as possible, leading to negative externalizations upon nature. 
ecological. This world construction occurs through innumerable practices from: the deforestation of the Brazilian rainforests for animal and monocrop agriculture; to the Green Revolution and the rise contemporary monocropping and the subsequent rise of "super weeds" and the increases of nitrous oxide in the atmosphere and fertilizer runoff in the oceans due to high uses of fertilizers [18] (p. 32) [38] (pp. 241-290); to the mining of rare metals for the production of electronics such as computers and cell phones and the subsequent shipping of lethal e-waste from the global north to the global south for recycling/dumping [79]; to the production of meat through industrialized practices of rearing, and abusing, animals that both uses up exorbitant volumes of land and water causing deforestation while also producing massive quantities of methane gas that represents approximately one-fifth of all greenhouse gasses in the world [59] (p. 134); to the organized and monetized extraction and burning of oil and the subsequent increase of carbon dioxide in the atmosphere [72], currently just above 400 parts per million (ppm) and well above the $350 \mathrm{ppm}$ that is commonly considered safe [82]; to the over 1200 coal-fired energy plants constructed throughout the world in 2014, which will only begin to procure a profit for their investors after decades of burning coal and releasing further Co2 [83]; to the production of new forms of life, such as high-producing crops that are being designed to enable future generations of the wealthy to consume at the rate they have become accustomed to [25]; etcetera-all of which while actively shaping and reshaping the atmosphere, geology, and biology of the world can only be thoughtfully and correctly understood when viewed as constituents and outcomes of the capitalist mode of production. These processes, despite the claims of some and the general tacit acceptance of the Anthropocenologists, are untenable, the finite planet has only so much materials that can be stripped for consumption and can absorb only so much of capitalism's excesses while remaining habitable for life.

Capital may and does make alterations to its production in the face of crisis and does employ new technologies which may serve to reduce the throughput needed as well as the waste produced and released through production processes. However, these changes represent facile alterations to the means of production and/or shifts in the materials being utilized in the production process [84], not qualitative alterations to the mode of production nor its logics-with such changes operating through a perpetually renewed process of acquisition and exhaustion of novel resources and lives from hinterlands, and the development of more efficient and, more importantly, cheaper means of production; rather than being concerned with the stabilization of human-nature relations. Modifications to production processes or the materials used in production may prolong relations, but the underlying logic of capital locks production into a perennial cycle of crisis as capital demands ceaseless expansion at the expense of nature [85,86]. For as John Bellamy Foster [87] points out, capital has caused a rift between humans and the rest of nature, disrupting more stable and reciprocal relations, or the "metabolism", historically maintained between humans and nature and initiating highly unstable and lopsided relations between humans, particularly that of the wealthy, and the rest of nature. Thus, despite the naïve claims by some that capital may be decoupled from the environment, current evidence suggests, in line with historical patterns, that accumulation, consumption, and pollution have and will likely continue to increase exponentially rather than decrease-as the Anthropocenologists have made blatantly clear.

As Justin McBrien [8] points out, capital is far more than a mode of production but is at the same time a becoming extinction. Indeed, McBrien offers the new neologism Necrocene in place of that of the Anthropocene as he notes that capitalism does not merely produce commodities and (re)shape nature, but feasts upon and produces death—as it consumes the fossilized energy of the dead buried for millennia; as it inevitably kills cultures, ecosystems, humans, and non-human animals; and as it currently threatens to put all life on the planet at risk of extinction. Each one of these extinctions shoots waves of suffering through individual animals, species, and the entangled web of human-nature relations, demanding serious ethical as well as pragmatic consideration [58]. Capital currently sits at the heart of humanity's relations with each other and nature, serving as the nexus through which humanity values, acts upon, shapes, and kills nature. By ignoring the role of capital, the Anthropocenologists 
incapacitate the Anthropocene as a solution formulation and instead make it a tool to facilitate capital's continued growth into the future, and thus facilitate the very extinction which they seek to prevent. As the Anthropocene attempts to address ecological crises without challenging the status quo, it is destined to fail, as Elmar Altvater [40] (p. 151) states,

Any effective response would need to be holistic; it would have to be qualitative and consider much more than price alone. But that is impossible because it contradicts capitalist rationality, which is committed to fixing the parts and not the whole.

\section{Planetary Management and Geoengineering-The "Solutions" of the Anthropocene}

The proposed concept of "planetary boundaries" lays the groundwork for shifting our approach to governance and management, away from the essentially sectorial analyses of limits to growth aimed at minimizing negative externalities, toward the estimation of the safe space for human development. Planetary boundaries define, as it were, the boundaries of the "planetary playing field" for humanity if we want to be sure of avoiding major human-induced environmental change on a global scale.-Rockstörm et al. [18] (p. 1)

There is little doubt in my mind that, as one of the characteristic features of the "anthropocene", distant future generations of "homo sapiens" will do all they can do to prevent a new ice-age from developing by adding powerful artificial greenhouse gases to the atmosphere. Similarly, any drop in Co2 levels to excessively low concentrations, leading to reductions in photosynthesis and agricultural productivity would be combated by artificial releases of Co2.-Crutzen [52] (p. 17)

Those who designated and espouse this new epoch of the Anthropocene have presented it as a solution formulation that will serve to bridge political divides and offer an "impartial" scientific response to ecological crises. As the two quotes above suggest, the Anthropocene offers two general responses to ecological crises in the form of the scientific management of humanity and the planet through the planetary boundaries system and through large-scale geoengineering of the Earth's systems to compensate for Humanity's impact upon nature. Furthermore, as Rockström et al. [18] (p. 1) suggest, the Anthropocene promises to resolve Humanity's impact on the Earth's geology, atmosphere, and biosphere while avoiding troublesome and unnecessary debates over how humanity operates. As Steffen et al. [25] point out, the planetary boundaries do not prescribe how Humanity should exist but rather marks the limits of its operations. However, due to this "neutrality", the "solutions" offered up from the Anthropocene do little more than enable the current modus operandi which has led to ecological crisis.

The first, and by far most heavily favored response to ecological crises is that of the planetary boundaries model, wherein "anthropogenic" effects are measured in a quantifiable system containing nine boundaries which are delineated in accordance to the pre-industrial Holocene epoch so as to define a "safe operating space" for Humanity. Each of the nine factors measured-climate change, biosphere integrity, land-system change, freshwater use, biochemical flows, ocean acidification, atmospheric aerosol loading, stratospheric ozone depletion, and novel entities [25] — contain three zones that indicate the current condition of each factor of the Earth System: the first zone is considered as the safe zone that resides below the set boundary; the second, the zone of uncertainty, resides above the boundary where ecological crises and collapse may occur; and the third, the zone beyond uncertainty, is where "anthropogenic" effects are very likely to cause ecological crises and collapse. Certain boundaries, such as the biosphere integrity and biochemical flows, contain multiple sub-measures so as to more accurately calculate and determine anthropogenic effects on nature, measuring genetic diversity as well as functional diversity ${ }^{41}$ and phosphorous and nitrogen flows,

41 A measure of the biodiversity required to ensure the functioning of biomes and the larger Earth System [25] (pp. 5-6). 
respectively. Furthermore, these boundaries have become increasingly intricate with initial steps already being taken to create regional and continental boundaries and some proposals emerging for even finer sub-regional measures and boundaries that will serve to measure anthropogenic effects on individual biomes and national provinces [25].

These boundaries are proposed to serve as the basis for new comprehensive governmental regulation of human-nature relations. While still in its infancy, the proposed solution would arguably collect global, regional, and sub-regional data on anthropogenic effects and deploy that data to inspire and inform governmental regulation $[4,50]$. This response is ambitious to the point of fault, assuming that all of humanity in its diversity of nations, regions, and groupings operating within interrelated webs of historical power relations and conflicting social and geopolitical goals can be brought under the wing of scientific management. And further, it is also alarming, as success would require massive institutional and social change as well as harsh new regulatory regimes [62] (p. 28) that would significantly impact countries' and most notably communities' wellbeing-particularly that of poorer nations currently undergoing industrialization, as they would likely suffer economic deprivation at the hands of such new regulation and enforcement.

Regardless, of this dismal possibility, the planetary boundary system is an unfeasible solution to ecological crises, refusing to address the underlining causes of ecological crises in favor of seeking unified support. The result is a toothless response that does too little too late. When looking to the boundaries themselves, we can see that there is little hope that they actually represent a legitimate and formidable response to ecological crisis. Of the nine planetary boundaries proposed so far four have already been transgressed with climate change and land-system change currently residing in the zone of uncertainty, and genetic diversity within the biosphere and biochemical flows having moved well beyond the zone of uncertainty, currently threating imminent ecosystem collapse and ecological crisis; and while ocean acidification is currently within the "safe" 42 zone it too is quickly approaching the zone of uncertainty and poses a serious threat to both ocean and non-ocean life [12]. Furthermore, two of the nine measures, novel entities (referring to any human-made chemical, material, or forms of life) and atmospheric aerosol loading, as well as the functional biodiversity measure of biosphere integrity, have yet to receive a specified boundary. However, a cursory boundary has been proposed for functional biodiversity which was found to have already been transgressed in the only region, southern Africa, it has been measured. This leaves only fresh water use, measured at the global and not regional scale, and stratospheric ozone depletion ${ }^{43}$ as the only two measures that are known to be comfortably within the zone of safety.

Furthermore, of these boundaries, climate change and biodiversity are considered to be the core determinates of the Earth's capacity to support life, affecting the entire planet's ability to regulate material and energy flows [25]. However, as already stated, both of these boundaries have already been exceeded, and if any solution is to be realized through this system, it would likely not be for centuries to come and only after these issues intensify to the point of being unbearable. For once these boundaries are crossed, they are not simply resolved by merely reducing "Humanity's" or even capital's impact upon the planet-as much of the carbon currently present in the atmosphere will be present for up to 500 years despite any attempts to mitigate greenhouse gas production [4] (p. 21) and the acidification of the ocean is expected to remain dangerously high well beyond the end of this century regardless of Humanity's/capital's impacts [12]. Moreover, the biodiversity already lost will take millennia to replace, and the species lost can never be replaced. Truly, the "Anthropocene"

42 This use of the term safe itself illustrates the humancentric and preferential use of the concept, as Elizabeth Kolbert [7] and the Royal Society [12] have shown the oceans and their life have already undergone massive alterations, with many species existence currently threatened.

43 Which while remaining in the safe zone, does tip into unsafe levels every year during the Austral spring [25] (p. 4). 
or, rather, the Capitalocene [38], has permanently etched itself into the Earth's biosphere, atmosphere, and geology remaking the planet and altering the course of nature forever ${ }^{44}$.

The planetary boundaries are a hollow solution, at best offering a system of measures with which one can quantify the deleterious effects wrought upon nature but which still provide no direct path forward, and at worst facilitate business as usual in its reluctance to openly challenge the destructive practices of accumulation and consumption. Through the planetary boundaries, the Anthropocenologists dream of a Humanity and Nature measured and managed in intricate nets of control. However, even this imagined net, if it were ever to materialize, would still be destined to fail due to its reluctance to engage the status quo, promising management and regulation without transformation - which will ultimately result in a perpetuation of the current destructive power/social relations. Indeed, as the Susan Baker [35], Ehlers and Krafft [36], and Frank Biermann [89] have all shown, concepts from Earth System Science and the Anthropocene have already been intermingled with and co-opted into UN and governmental responses to ecological crisis and environmental change, as well as those nations' and organizations' calls for future "progress" and economic growth. Furthermore, the planetary boundaries system is not an autonomous solution as it is reliant on either governments that have historically aided the growth of and been influenced by capital [34] and/or upon the world constructing power of geoengineering, which is argued to hold the potential to mitigate Humanity's impact upon nature and possibly to optimize nature for Humanity $[36,52] .{ }^{45}$ So, the planetary boundaries, while providing important information on the likelihood and interconnectedness of ecological crises, do little by way of offering solutions to crisis.

The second solution offered up through the Anthropocene literature is that of geoengineering of the Earth's systems so as to counterbalance Humanity's prodigious effects upon nature. As already stated, geoengineering has been a persistent element of the Anthropocene literature, present in the first article published on the Anthropocene [1], and repeated in each subsequent year of research, with ever more common and intensified calls for the testing and deployment of geoengineering as a method to resolve ecological crises. However, despite geoengineering's common appearance in the Anthropocene literature, it is by no means celebrated by the Anthropocenologists. Rather, it appears to represent the Anthropocenologists somber recognition of the severity of the ongoing and developing crises and the incompetence of governments to realistically address such overwhelming processes. As Paul Crutzen [10] (pp. 211-212) points out, while large-scale geoengineering is not an ideal solution, ${ }^{46}$ it is becoming an increasingly necessary tool in the face of governments' "grossly unsuccessful" attempts to mitigate impacts on nature.

Manifold techniques and technologies have now arisen that hold out the promise of preserving the environment, or at least preserving its habitability, for Humanity through technological intervention into nature's systems. Proposed methods of geoengineering range widely from calls to capture and sequester carbon from the atmosphere for future use as a fuel source, to painting the roofs of cities white so as to reflect light back into space, to covering deserts with reflective material and/or making clouds whiter, to distributing dust or reflective pieces of metal into orbit around the planet to block incoming light, to seeding the oceans with iron so as to encourage the bloom of phytoplankton that will absorb carbon from the atmosphere, to dispersing sulphate aerosols into the atmosphere as a way to reflect the sun's light back into space, thus cooling the planet [53] (pp. 24-34). However, each proposal suffers from the same limitations; first, these proposals do not address the drivers of ecological crises but merely their result, and second, each proposal is a partial measure only addressing one element

44 Indeed, it appears that we have entered into what Bruno Latour [88] refers to as the "new climatic regime", wherein there has been a profound and irreversible shift in the relationship between humans and the rest of nature with the physical world having become unstable, refusing to be seen as a passive stage for our activities or to simply bend to our wills.

45 See also, Altvater [40].

46 Some, like Nigel Clark [62], suggest that geoengineering may be read as the nascent expression of the larger issue of governing in the Anthropocene, representing our first steps towards conceptualizing and imagining responses to ecological crisis. 
of ecological crises, predominately climate change. Furthermore, many, if not all, of these proposed responses cause their own devastating effects.

To take the example of stratospheric aerosol loading, by far the most advocated [4] (p. 28) [5] (p. 752) $[6,10,52]$ (p. 17) [54] (pp. 46-72) and currently the most feasible technique for responding to ecological crises, we can see such limitations to geoengineering. Inspired by the 1991 eruption of Mount Pinatubo, which injected $10 \mathrm{Tg}$ (million tonnes) of sulphur particles into the stratosphere which acted to reflect some of the sun's light back into space, causing a $0.5^{\circ} \mathrm{C}$ drop in the world's temperature [10] (p. 212), the Anthropocene literature has taken up and made repeated proposals to mimic this eruption by purposefully injecting sulphate aerosols into the stratosphere through the deployment of balloons carrying So2 particles or shooting So2 into the stratosphere via artillery guns. These techniques, like the eruption, would reflect the sun's light back into space, reducing the amount of heat absorbed by the planet and thus causing a drop in the Earth's temperature. This response does have the potential to reverse climate change and could conceivably work indefinitely even with increased Co2 emissions, that is assuming aerosols released continually match the greenhouse effect caused by the release of the $\mathrm{Co} 2[10,54]$. Another advantage of aerosol loading is that it could, if needed, be discontinued relatively quickly, as aerosols in the atmosphere deteriorate or drift to the Earth after two years.

However, the logistics and limitations of such aerosol loading are worth noting. To effectively mitigate current levels of greenhouse gases would require the continuous deployment of 1-2 Tg of sulphur to be released per year at an average cost of 25-50 billion dollars (US) [10] (p. 212). As Co2 levels are expected to increase into the foreseeable future, so too would the needed injections of sulphur along with its costs both financial and otherwise. While the Anthropocenologists remind us that this cost is minimal compared to the cost of the disasters that would arise from climate change, it is important to remember that this "solution" does not actually solve anything but rather requires a continuous ratcheting up of human organization/response as well as chemical deployment to match and mitigate the production of $\mathrm{Co}$. Furthermore, as mentioned above, aerosol loading like all geoengineering operates as a singular techno-fix rather than a holistic solution, resolving only one aspect of the current crisis. Addressing climate change through sulphate injection does nothing to stop the acidification of the oceans, or the collapse of ecosystems due to the loss of biodiversity through destructive practices of logging and agriculture, or the subsequent flows of nitrogen and phosphorous into ecosystems. In fact, it does little to nothing to address the eight other boundaries created by the Anthropocenologists but does exacerbate stratospheric ozone depletion (see below). Thus, geoengineering does not solve anything but rather serves to stave off crisis through a patchwork of techno-fixes that enable life, particularly that of human life, to continue.

Furthermore, the consequences of aerosol injection may be as alarming as the consequences of climate change. As already suggested, sulphate aerosols disrupt chemical processes in the stratosphere, triggering ozone depletion and consequently increasing the risk of cancer to humans [10] (pp. 215-216). This, however, is only one of the many effects of aerosol injection. Harvard physicist David Keith ${ }^{47}$ goes over the known consequences of sulphate aerosol injections in his book, A Case for Climate Engineering [54], pointing out that sulphate injections would: make the days cooler and the nights warmer (due to the continued presence of greenhouse gases), do the same to summer and winter, make the sky turn whiter with each cycle of injections, upset precipitation patterns (likely making the planet dryer), altering if not halting the Indian Monsoon, disrupting photosynthesis and the efficiency of solar panels (due to the decreased light reaching the planet's surface), contributing to thousands of premature human deaths ${ }^{48}$ each year due to the inhalation of falling sulphate particles, and possibly causing acid rain. These only represent the known and probable consequences of aerosol injections, with both Keith [54] and Crutzen [10] agreeing that there are likely further consequences that can

47 Keith is currently the head of a group of Harvard Scientists, the Keith Group, which is actively studying the possibilities, effects, and implications of geoengineering in hopes of developing a geoengineered response to climate change [90].

48 To my knowledge, no research has as of yet examined how of sulphuric aerosol injection would impact non-human life. 
only be known after large-scale deployment of sulphates. As Melinda Cooper [91] (p. 74) points out, the paradox of geoengineering is that

... it calls for a strategic intervention into the atmosphere in order to pre-empt the worst effects of climate change, while acknowledging that such an intervention may itself be indistinguishable from the process of climate change-that is to say, equally unpredictable, incalculable and turbulent in its unfolding.

Finally, despite the claims of its scientific neutrality, geoengineering does carry with it political implications [37]. As Timothy Luke [33,92] points out, technology is never absent of politics, but is property and as such carries with it politics; those who geoengineer the planet's systems do it for all regardless of oppositions, one does not geoengineer the atmosphere over the US solely or merely the ocean near China. In making a choice to geoengineer the planet's systems one, be it a nation or coalition of nations, decides the course of life for the entire planet, not merely for a nation and not merely for humans, but all life, with innumerable impacts being felt well into the future. All this for a "solution" that does not solve but perpetuates the hegemonic capitalist relations that have caused ecological crises [33,37,83,92]. As Malm [83] (p. 191) points out, we have come to the unacceptable position where the planning of the economy has become the ultimate taboo but where planning the climate and functioning of the Earth is worthy of close consideration.

The Anthropocene has been offered up as a solution formulation, as the nexus or apparatus through which Humanity can come to grips with its impacts upon the planet and move towards solutions. However, no solution can be found in the Anthropocene, as it offers nothing but impractical and frankly dangerous governmental regulation on one hand and on the other a network of technological fixes that at best serve to stave off ecological crisis and at worst cause them itself. The Anthropocenologists refuse to address the causes of the current crises and thus resign themselves to address these crises' epiphenomena, for to adequately respond to the conditions of the Anthropocene one must turn to its source, the current mode of production and consumption.

\section{Conclusions}

What sets humanity apart [from other animals] is that its modes of production of its ecosystems-its modes of production of nature-are historical; humans are, however incompletely, conscious of the production of nature and through this consciousness can seek to direct that production.-Millar and Mitchell [29] (p. 83 [emphasis in original])

Steffen, Crutzen, and McNeil [6] present us with three options for the future: the first option, "business as usual", is where Humanity stays on its current trajectory and descends into certain catastrophe; the second option, "mitigation", is one where Humanity rallies together around scientific data and the nine planetary boundaries in order to mollify Humanity's impact upon nature; and the third option, "geoengineering", is one in which Humanity, unable or unwilling to mitigate its impact on the planet, compensates for this impact by reforming the planet itself through the power of technology. All three are of course false choices, all present the false view of Humanity as the focal point of ecological crises while at the same time pretending that these options are separate routes that Humanity may take when in reality it is far more likely that if we, or at least some of us, are to continue in the imaginary that permeates the Anthropocene-continuing to see the world through the ahistorical, humancentric, and dualistic lens that undergirds it-Humanity will likely do all three at once; mitigating to some extent but largely operating as usual until the problem gets so intolerable that humans are forced to (re)shape the atmosphere and innumerable other systems so as to preserve Humanity and the handful of species that we are capable of saving and deem valuable enough to save. It may be true that through the imaginary of the Anthropocene humans can deploy government and technology so as to ensure survival, at least our own, into the future, at least for some time. However, whatever new assemblages of $(\mathrm{H} / \mathrm{h})$ umanity and nature that emerges from these "solutions" would surely be considered a failure from the perspective of those in the current world. 
The Anthropocene promises solutions but is underpinned by a set of misconceptions that make it barren ground for such solutions. The Anthropocenologists mark Humanity as innately at odds with nature, and in so doing they misconceive and misappropriate blame for ecological crisis onto all humans regardless of culpability. Further, they reify a fabricated Cartesian dualism between nature and humanity and reduce history to a set of technological advances and historical effects. It is this tripartite reductionism which runs throughout the Anthropocene discourse that obfuscates and prevents any effective response to ecological crises, directing those who use this prism toward responses that seek to manage both Humanity and nature and to reshape and optimize the latter for the former while leaving capitalist production and consumption unchallenged. That is, through this imaginary, we are driven toward the false solutions of unified and intricate management over humanity and nature and toward the geoengineering of the planet for Humanity, both of which are fated to fail as they blindly work to address the epiphenomena of capital misconceiving its logics and operations, as well as the actions that many contemporary humans carry out through capital as an innate aspect of humanity.

Counter to the imaginary of the Anthropocene, the world is constantly (re)shaped through the nexus of capital, through its valuation of nature, its flows of money, its destructive but cost-effective practices of production, and through the exorbitant consumption of commodities by some-rightfully being called the Capitalocene. Only through a recognition and challenge of the current mode of production as a powerful but historical social system embedded in nature can we hope to restructure our social and extra-social relations to produce radically different societies which do not generate ceaseless cycles of crisis. Through the nexus of capitalism, humanity manufactures ecological crisis and the extinction of species, possibly even our own, constructing a barren and lonelier world, perhaps the Necrocene ${ }^{49}$ or Homogenocene ${ }^{50}$ ? - the Anthropocene's solutions do little to prevent this; capital itself must be challenged in order cease such crises. As Justin McBrien [8] (p. 135) so poignantly states, "The logic of accumulation is not capable of outrunning extinction, because accumulation and extinction are the same process. They cannot be decoupled. But, the human being can be decoupled from capital".

This decoupling from capital accumulation will require both a critical questioning of our present as well as for dramatic reimaginings of our modes of existence. We will thus need to move away from the terminally flawed Anthropocene and enter into what Howe and Pandian [94] refer to as the Betacene, "a time to test, engage, and experiment with new ways of being in the world and with the world". What is required, then, are radically democratic and skeptical eco-social movements, and the construction of new commons wherein new knowledges and ways of being can be formed independently from the logics of capital $[64,65,95]$. This work of reimaging our ontology has already been started by Marxists and posthumanists and is already existent in the lives of those who exist at the violent fringes of capital accumulation [67] and within the emergent democratic knowledge communities and climate justice movements mapped out by Anna Tsing [64] and Ashley Dawson [65]. Ecological crises cannot be solved, too much destruction has already been wrought for anything to be considered a solution. However, we may move toward more peaceable relations with each other and the rest of nature through a decoupling of ourselves from the system of capital at the heart of ecological crisis. To do otherwise, to continue in the imaginary of the Anthropocene, is to accept and facilitate the impending crises of capital.

Conflicts of Interest: The author declares no conflict of interest.

49 See Justin McBrien [8].

50 A more informal title used to problematize the Anthropocene, which describes the homogenization of life on the planet from the effects of humans and/or capital [93]. 


\section{References}

1. Crutzen, P.J.; Stoermer, E. The "Anthropocene". Glob. Change News Lett. 2000, 41, 17-18.

2. Crutzen, P.J. Geology of mankind. Nature 2002, 415, 23. [CrossRef] [PubMed]

3. Luke, T.W. On Environmentality: Geo-Power and Eco-Knowledge in the Discourses of Contemporary Environmentalism. Cult. Crit. 1995, 31, 57-81. [CrossRef]

4. Steffan, W. A Truly Complex and Diabolical Policy Problem. In The Oxford Handbook of Climate Change and Society; Dryzek, J., Norgaard, R., Schlosberg, D., Eds.; Oxford University Press: Oxford, UK, 2011; pp. 21-37.

5. Steffen, W.; Persson, Å.; Deutsch, L.; Zalasiewicz, J.; Williams, M.; Richardson, K.; Crumley, C.; Crutzen, P.; Folke, C.; Gordon, L.; et al. The Anthropocene: From Global Change to Planetary Stewardship. AMBIO 2011, 40, 739-761. [CrossRef] [PubMed]

6. Steffen, W.; Crutzen, P.J.; McNeill, J.R. The Anthropocene: Are Humans Now Overwhelming the Great Forces of Nature? AMBIO 2007, 36, 614-621. [CrossRef]

7. Kolbert, E. The Sixth Extinction: An Unnatural History; Henry Holt and Company: New York, NY, USA, 2014.

8. McBrien, J. Accumulation Extinction: Planetary Catastrophism in the Necrocene. In Anthropocene or Capitalocene?: Nature, History, and the Crisis of Capitalism; Moore, J., Ed.; PM Press: Dexter, OH, USA, 2016; pp. 116-137.

9. Crutzen, P.J. The Effects of Industrial and Agricultural Practices on Atmospheric Chemistry and Climate During the Anthropocene. J. Environ. Sci. Health Part A 2002, 37, 423-424. [CrossRef]

10. Crutzen, P.J. Albedo Enhancement by Stratospheric Sulfur Injections: A Contribution to Resolve a Policy Dilemma? Clim. Chang. 2006, 77, 211-219. [CrossRef]

11. Crutzen, P.J.; Mosier, A.R.; Smith, K.A.; Winimater, W. $\mathrm{N}_{2} \mathrm{O}$ Release from Agro-Biofuel Production Negates Global Warming Reduction by Replacing Fossil Fuels. Atmos. Chem. Phys. 2008, 8, 389-395. [CrossRef]

12. Royal Society. Ocean Acidification due to Increasing Carbon Dioxide; The Royal Society: London, UK, 2005.

13. Zalasiewicz, J.; Williams, M.; Smith, A.; Barry, T.L.; Coe, A.A.; Brown, P.R.; Brenchley, P.; Cantrill, D.; Gale, A.; Gibbard, P.; et al. Are we now living in the Anthropocene? GSA Today 2008, 18, 4-8. [CrossRef]

14. Crist, E. On the Poverty of Nomenclature. In Anthropocene or Capitalocene?: Nature, History, and the Crisis of Capitalism; Moore, J., Ed.; PM Press: Dexter, OH, USA, 2016; pp. 14-33.

15. Costanza, R.; Graumlich, L.; Steffen, W.; Crumley, C.; Dearing, J.; Hibbard, K.; Leemans, R.; Redman, C.; Schimel, D. Sustainability or Collapse: What Can We Learn from Integrating the History of Humans and the Rest of Nature? AMBIO 2007, 36, 522-527. [CrossRef]

16. Crist, E. Beyond the climate crisis: A critique of climate change discourse. Telos 2007, 141, $29-55$.

17. Bonneuil, C.; Fressoz, J.-B. The Shock of the Anthropocene: The Earh, History and Us; Verso: London, UK; New York, NY, USA, 2015.

18. Rockström, J.; Steffen, W.; Noone, K.; Persson, Å.; Chapin, F.S.I.; Lambin, E.; Lenton, T.; Scheffer, M.; Folke, C.; Schellnhuber, H.J.; et al. Planetary Boundaries: Exploring the Safe Operating Space for Humanity. Ecol. Soc. 2009, 14, 1-32. [CrossRef]

19. Steffen, W.; Grinevald, J.; Crutzen, P.; McNeill, J. The Anthropocene: Conceptual and historical perspectives. Philos. Trans. R. Soc. Lond. Math. Phys. Eng. Sci. 2011, 369, 842-867. [CrossRef] [PubMed]

20. Nimmo, R. Apiculture in the Anthropocene: Between Posthumanism and Critical Animal Studies. In Animals in the Anthropocene: Critical Perspectives on Non-Human Futures; Sydney University Press: Sydney, Australia, 2015; pp. 177-199.

21. Bai, X.; van der Leeuw, S.; O’Brien, K.; Berkhout, F.; Biermann, F.; Brondizio, E.S.; Cudennec, C.; Dearing, J.; Duraiappah, A.; Glaser, M.; et al. Plausible and desirable futures in the Anthropocene: A new research agenda. Glob. Environ. Chang. Hum. Policy Dimens. 2016, 39, 351-362. [CrossRef]

22. Weart, S. The Development of the Concept of Dangerous Anthropogenic Climate Change. In The Oxford Handbook of Climate Change and Society; Dryzek, J., Norgaard, R., Schlosberg, D., Eds.; Oxford University Press: Oxford, UK, 2011; pp. 67-81.

23. Latour, B. Waiting on Gaia. Composing the Common world Through Arts and Politics. Equilibri 2012, 16, $515-538$.

24. Lövbrand, E.; Stripple, J.; Wiman, B. Earth System governmentality. Reflections on science in the Anthropocene. Glob. Environ. Chang. 2009, 19, 7-13. [CrossRef] 
25. Steffen, W.; Richardson, K.; Rockström, J.; Cornell, S.E.; Fetzer, I.; Bennett, E.M.; Biggs, R.; Carpenter, S.R.; de Vries, W.; de Wit, C.A.; et al. Planetary boundaries: Guiding human development on a changing planet. Science 2015, 347, 1259855. [CrossRef] [PubMed]

26. Ellis, E.C. Ecology in an anthropogenic biosphere. Ecol. Monogr. 2015, 85, 287-331. [CrossRef]

27. Steffen, W.; Sanderson, R.A.; Tyson, P.D.; Jäger, J.; Matson, P.A.; Moore, B., III; Oldfield, F.; Richardson, K.; Schellnhuber, H.J.; Turner, B.T.; et al. Global Change and the Earth System: A Planet Under Pressure; Global Change-The IGBP Series; Springer: Berlin/Heidelberg, Germany, 2005; ISBN 978-3-540-26594-8.

28. Zalasiewicz, J.; Waters, C. The Anthropocene. Oxf. Res. Encycl. Environ. Sci. 2015. [CrossRef]

29. Millar, S.W.S.; Mitchell, D. The Tight Dialectic: The Anthropocene and the Capitalist Production of Nature. Antipode 2017, 49, 75-93. [CrossRef]

30. Raupach, M.R.; Canadell, J.G. Carbon and the Anthropocene. Curr. Opin. Environ. Sustain. 2010, 2, $210-218$. [CrossRef]

31. Crutzen, P.J.; Steffen, W. How long have we been in the Anthropocene era? Clim. Chang. 2003, 61, $251-257$. [CrossRef]

32. Moore, J. Introduction: Anthropocene or Capitalocene?: Nature, History, and the Crisis of Capitalism. In Anthropocene or Capitalocene?: Nature, History, and the Crisis of Capitalism; Moore, J., Ed.; PM Press: Dexter, OH, USA, 2016; pp. 1-11.

33. Luke, T.W. Geoengineering as global climate change policy. Crit. Policy Stud. 2010, 4, 111-126. [CrossRef]

34. Parenti, C. Environment-Making in the Capitalocene Political Ecology of the State. In Anthropocene or Capitalocene?: Nature, History, and the Crisis of Capitalism; Moore, J., Ed.; PM Press: Dexter, OH, USA, 2016; pp. 166-184.

35. Baker, S. Governance. In Critical Environmental Politics; Death, C., Ed.; Routledge: New York, NY, USA; London, UK, 2014; pp. 100-110.

36. Ehlers, E.; Krafft, T. Managing Global Change: Earth System Science in the Anthropocene. In Earth System Science in the Anthropocene Emerging Issues and Problems; Ehlers, E., Krafft, T., Eds.; Springer: New York, NY, USA, 2006; pp. 5-16.

37. Sikka, T. A critical discourse analysis of geoengineering advocacy. Crit. Discourse Stud. 2012, 9, 163-175. [CrossRef]

38. Moore, J. Capitalism in the Web of Life: Ecology and the Accumulation of Capital; Verso: London, UK; New York, NY, USA, 2015.

39. Moore, J. The Rise of Cheap Nature. In Anthropocene or Capitalocene?: Nature, History, and the Crisis of Capitalism; PM Press: Dexter, OH, USA, 2016; pp. 78-115.

40. Altvater, E. The Capitalocene, or, Geoengineering Against Capitalism's Planetary Boundaries. In Anthropocene or Capitalocene?: Nature, History, and the Crisis of Capitalism; Moore, J., Ed.; PM Press: Dexter, OH, USA, 2016; pp. 138-152.

41. Hartley, D. Anthropocene, Capitalocene, and the Problem of Culture. In Anthropocene or Capitalocene?: Nature, History, and the Crisis of Capitalism; Moore, J., Ed.; PM Press: Dexter, OH, USA, 2016; pp. 154-165.

42. Haraway, D. Anthropocene, Capitalocene, Plantationocene, Chthulucene: Making Kin. Environ. Humanit. 2015, 6, 159-165. [CrossRef]

43. Haraway, D. Staying with the Trouble: Anthropocene, Capitalocene, Cthulecene. In Anthropocene or Capitalocene?: Nature, History, and the Crisis of Capitalism; Moore, J., Ed.; PM Press: Dexter, OH, USA, 2016; pp. 33-77.

44. Ison, R. Governing in the Anthropocene: What Future Systems Thinking in Practice? Syst. Res. Behav. Sci. 2016, 33, 595-613. [CrossRef]

45. Lövbrand, E.; Beck, S.; Chilvers, J.; Forsyth, T.; Hedrén, J.; Hulme, M.; Lidskog, R.; Vasileiadou, E. Who speaks for the future of Earth? How critical social science can extend the conversation on the Anthropocene. Glob. Environ. Chang. 2015, 32, 211-218. [CrossRef]

46. Malm, A.; Hornbor, A. The Geology of Mankind? A Critique of the Anthropocene Narrative. Anthr. Rev. 2014, 1, 62-69. [CrossRef]

47. Moore, J.W. The Capitalocene, Part I: On the nature and origins of our ecological crisis. J. Peasant Stud. 2017, 44, 594-630. [CrossRef]

48. Schneiderman, J. Naming the Anthropocene. Philosopia 2015, 5, 179-201. 
49. Sharp, H. Endangered Life: Feminist Posthumanism in the Anthropocene. In Feminist Philosophies of Life; Sharp, H., Taylor, C., Eds.; McGill-Queen's University Press: Montreal, QC, Canada; London, UK, 2016; pp. 272-282.

50. Steffen, W.; Smith, M.S. Planetary boundaries, equity and global sustainability: Why wealthy countries could benefit from more equity. Curr. Opin. Environ. Sustain. 2013, 5, 403-408. [CrossRef]

51. Robinson, N.A. Beyond sustainability: Environmental management for the Anthropocene Epoch. J. Public Aff. 2012, 12, 181-194. [CrossRef]

52. Crutzen, P. The Anthropocene. In Earth System Science in the Anthropocene: Emerging Issues and Problems; Ehlers, E., Krafft, T., Eds.; Springer: New York, NY, USA, 2006; pp. 13-18.

53. Royal Society. Geoengineering the Climate: Science, Governance and Uncertainty; Royal Society: London, UK, 2009.

54. Keith, D. A Case for Climate Engineering; MIT Press: Cambridge, MA, USA, 2013.

55. Chakrabarty, D. The Climate of History: Four Theses. Crit. Inq. 2009, 35, 197-222. [CrossRef]

56. Tuana, N. Being Affected by Climate Change the Anthropocene and the body of Ethics. In Ethics and the Anthropocene; Shockley, K., Light, A., Eds.; MIT Press: Cambridge, MA, USA, forthcoming; pp. 1-13.

57. Zalasiewicz, J.; Williams, M.; Haywood, A.; Ellis, M. The Anthropocene: A new epoch of geological time? Philos. Trans. R. Soc. Lond. Math. Phys. Eng. Sci. A 2011, 369, 835-841. [CrossRef] [PubMed]

58. Van Dooren, T. Pain of Extinction: The Death of a Vulture. Cult. Stud. Rev. 2010, 16, 271-289. [CrossRef]

59. Weis, T. The Ecological Hoofprint: The Global Burden of Industrial Livestock; Zed Books: London, UK, 2013.

60. Colebrook, C. Feminist Extinction: The Bloated Monster. In Sex After Life: Essays on Extinction; Colebrook, C., Ed.; Open Humanities Press: Ann Arbor, MI, USA, 2014; Volume 2, pp. 7-22.

61. Foster, J.B. Marxism in the Anthropocene: Dialectical Rifts on the Left. Int. Crit. Thought 2016, 6, $393-421$. [CrossRef]

62. Clark, N. Geo-politics and the disaster of the Anthropocene. Sociol. Rev. 2014, 62, 19-37. [CrossRef]

63. Ogden, L.; Heynen, N.; Oslender, U.; West, P.; Kassam, K.-A.; Robbins, P. Global assemblages, resilience, and Earth Stewardship in the Anthropocene. Front. Ecol. Environ. 2013, 11, 341-347. [CrossRef]

64. Tsing, A. Arts of Inclusion, or How to Love a Mushroom. Manoa 2010, 22, 191-203.

65. Dawson, A. Climate Justice: The Emerging Movement against Green Capitalism. S. Atl. Q. 2010, 109, $313-338$. [CrossRef]

66. Mies, M.; Bennholdt-Thomsen, V. The Subsistence Perspective: Beyond the Globalized Economy; Zed Books: London, UK; New York, NY, USA, 2000.

67. Martinez-Alier, J. The Environmentalism of the Poor. Geoforum 2014, 55, 239-241. [CrossRef]

68. Malm, A. Steam: Nineteenth-Century Mechanization and the Power of Capital. In Ecology and Power: Struggles over Land and Material Resources in the Past, Present, and Future; Hornborg, A., Clark, B., Hermele, K., Eds.; Routledge: London, UK; New York, NY, USA, 2012; pp. 108-123.

69. Malm, A. The Origins of Fossil Capital: From Water to Steam in the British Cotton Industry*. Hist. Mater. 2013, 21, 15-68. [CrossRef]

70. Marx, K. Capital: A Critique of Political Economy; Progress: Moscow, Russia, 1954; Volume 1.

71. Marx, K. Grundrisse: Foundations of the Critique of Political Economy (Rough Draft); Allen Lane: London, UK, 1973.

72. Altvater, E. The Social and Natural Environment of Fossil Capitalism. Social. Regist. 2007, 43, 37-59.

73. Robins, R. Global Problems and the Culture of Capitalism; Pearson: Boston, MA, USA, 2014; Volume 6.

74. Foucault, M. Discipline and Punish: The Birth of the Prison; Vintage Books: New York, NY, USA, 1995.

75. Foucault, M. The Birth of Biopolitics: Lectures at the College de France 1978-1979; Senellart, M., Ed.; Picador: New York, NY, USA, 2008.

76. Marx, K.; Engels, F. The Communist Manifesto. In Karl Marx: Selected Writings, 2nd ed.; McLellan, D., Ed.; Oxford University Press: New York, NY, USA, 2000; Volume 2, pp. 245-255.

77. Marx, K. Capital: The Process of Capitalist Production as a Whole; International Publishers: New York, NY, USA, 1959; Volume 3.

78. Weber, M. The Protestant Ethic and the Spirit of Capitalism; Routledge: London, UK, 1992.

79. Surak, S. Capitalist logics, pollution management, and the regulation of harm: Economic responses to the problem of waste electronics. Capital. Nat. Social. 2016, 27, 106-122. [CrossRef] 
80. Heede, R. Tracing anthropogenic carbon dioxide and methane emissions to fossil fuel and cement producers, 1854-2010. Clim. Change 2014, 122, 229-241. [CrossRef]

81. Brown, W. Undoing the Demos: Neoliberalism's Stealth Revolution; Zone Books: Cambridge, MA, USA; London, UK, 2015.

82. IPCC. Climate Change 2014: Synthesis Report; Intergovernmental Panel on Climate Change: Geneva, Switzerland, 2014.

83. Malm, A. Socialism or Barbeque? war communism or geoengineering: some thoughts on choices in a time of emergency. In The Politics of Ecosocialism: Transforming Welfare; Borgas, K., Eskelinen, T., Perkio, J., Warlenius, R., Eds.; Routledge: London, UK, 2015; pp. 180-194.

84. Clark, B.; York, R. Rifts and shifts: Getting to the Root of Environmental Crises. Mon. Rev. 2008, 60, $13-24$. [CrossRef]

85. Clark, B.; York, R. Dialectical Materialism and Nature: An Alternative to Economism and Deep Ecology. Organ. Environ. 2005, 18, 318-337. [CrossRef]

86. Clark, B.; York, R. Techno-Fix: Ecological Rifts and Capital Rifts. In Ecology and Power: Struggles over Land and Material Resources in the Past, Present, and Future; Hornborg, A., Clark, B., Hermele, K., Eds.; Routledge: London, UK; New York, NY, USA, 2013; pp. 23-36.

87. Foster, J.B. Marx's Theory of Metabolic Rift: Classical Foundations for Environmental Sociology. Am. J. Sociol. 1999, 105, 366-405. [CrossRef]

88. Latour, B. Facing Gaia: Eight Lectures on the New Climatic Regime; Polity Press: Cambridge, MA, USA, 2017; ISBN 978-0-7456-8437-6.

89. Biermann, F. The Anthropocene: A governance perspective. Anthr. Rev. 2014, 1, 57-61. [CrossRef]

90. Projects. Available online: https:// keith.seas.harvard.edu/projects (accessed on 17 March 2018).

91. Cooper, M. Turbulent Worlds: Financial Markets and Environmental Crises. Theory Cult. Soc. 2010, 27, 167-190. [CrossRef]

92. Luke, T. Technology. In Critical Environment Politics; Death, C., Ed.; Routledge: New York, NY, USA, 2015; pp. 267-276.

93. Ivakhiv, A. Against the Anthropocene. In Immanence Ecoculture Geophilosophy Mediapolitics; University of Vermont: Burlington, VT, USA, 2014.

94. Howe, C.; Pandian, A. Introduction: Lexicon for an Anthropocene Yet Unseen-Cultural Anthropology. Available online: https://culanth.org/fieldsights/788-introduction-lexicon-for-an-anthropocene-yetunseen (accessed on 28 April 2018).

95. Dawson, A. Biohazard: The Catastrophic Temporality of Green Capitalism. Soc. Text 2013, 31, 63-81. [CrossRef]

(C) 2018 by the author. Licensee MDPI, Basel, Switzerland. This article is an open access article distributed under the terms and conditions of the Creative Commons Attribution (CC BY) license (http://creativecommons.org/licenses/by/4.0/). 